\title{
上腕骨外科澒骨折に対する横止め髄内釘固定法の経験
}

\begin{tabular}{|c|c|c|c|c|c|}
\hline 寺 & 戸 & 一 & 成. 坂 & 本 & 央 \\
\hline 利 & 光 & 哲 & 也 · 山 & 口 & 智太郎 \\
\hline 冨 & 重 & & 治·馬 & 渡 & 太 \\
\hline 植 & 田 & 博 & 也 - 中 & 村 & 哲 \\
\hline 川 & 村 & 秀 & 哉 & & \\
\hline
\end{tabular}

\section{Interlocking Intramedullary Nailing for Surgical Neck Fractures of The Humerus}

\author{
Kazushige Terado, Hisashi Sakamoto, Tetsuya Toshimitsu, \\ Tomotaro Yamaguchi, Osamu Tomishige, Taro Mawatari, \\ Hiroya Ueda, Tetsuro Nakamura, and Hideya Kawamura \\ Department of Orthopaedic Surgery, \\ Kyushu Kouseinenkin Hospital, Kitakyushu, Japan
}

The purpose of this study was to evaluate the results of interlocking intramedullary nailing for surgical neck fractures of the humerus. We used the ACE humeral nail system which others the advantage of transfixing locking screws for reliable fixation.

From 1997 to 1999, 7 consecutive displaced 2-part surgical neck fractures of the humerus were antegrade nailed with the ACE humeral nail system. The average age of the patients was 61.9 years (range 43 to 80 ). There were 2 males and 5 females and the average follow-up period was 12.9 months (range 5 to 29). All shoulders were assessed retrospectively and scored using the JOA shoulder scoring system.

All fractures achieved union and there was no delayed union, but one shoulder showed severe varus deformity radiographically. The average JOA score at final follow-up was 85.5 (range 75.5 to 95 ). The shoulders had an average active flexion of 130 degrees active abduction of, 131 degrees active external rotation of 55 degrees and internal rotation to the 9th thoracic vertebra. Due to technical errors, one patient had subacromial impingement caused by the protrusion of the proximal nail tip.

The operative method reported here otters the advantages of enabling sufficient fixation for osteoporotic cases. It is a useful alternative for the treatment of displaced surgical neck fractures of the humerus.

Key words : surgical neck of humerus (上腕骨外科澒), interlocking nail（横止め髄内釘), fracture (骨折)

$$
\text { はじめに }
$$

上腕骨近位端骨折は日常比較的多く見られる骨折で あり, その多くは Neer 分類の minimal displace- ment 例 4 であり保存治療の適応となる。しかし一部 には骨折部の転位の整復が困難であったり，整復位の 保持が困難なために手術治療が必要となる例がある. 手術の内固定材料としては従来より Kirschner 鋼線, 
Ender 釷，プレートなどが用いられ種々の手術手技 が行われてきたが，各々利点と欠点を有し，確立され たものはないのが現状である.

当科では 1997 年より，手術を必要とする上腕骨近 位端骨折のうち Neer 分類の 2-part 外科頚骨折に対 して，より強固な固定性の獲得を目的として Ace 社 製上腕骨髄内釷（以下 ACE 髄内釷）を用いた横止め 髄内釷固定法を行ってきた。今回その治療成績を検討 し報告する。

Ace 䯣内釘はいったん腱板を切開して上腕骨頭関 節面から順行性に刺入するチタン製の中空髄内釷で, 近位側に 3 本，遠位側に 2 本の横止螺子が挿入可能 である。また近位端のエンドキャップを挿入すること により最近位の横止め螺子をロックしこの脱落を防止 できる，手術後は患肢は三角筋とバストバンドで体幹 固定とし，創痛と創からの出血が始まり次第，数日以 内に肩掞よび肘の可動域訓練を開始した。

\section{対象}

1997 年 12 月から 1999 年 10 月までに当科で Ace 髄内釷を用いて横止め髄内釘固定法を行った Neer 分 類の 2-part外科頚骨折の 7 例を対象とした。内訳は 男 2 例女 5 例で, 手術時年令は平均 61.9 才（43 才〜 80 才), 術後経過観察期間は平均 12.9 力月（5力月～
29 カ月）であった.

術後臨床成績を日整会肩関節疾患治療成績判定基準 （以下 JOA スコア）で評価し，また患側と健側の肩 関節可動域を測定した。

$$
\text { 結果 }
$$

骨癒合は全例で順調に得られ，経過中に遷延癒合や 偽関節を呈したものはなかった，調査時 JOA スコア 総合点は平均 85.5 点（75.5 95 点）であった. 内訳 の各々の平均は疼痛点 22.5 点, 外転筋力の強さ 4.25 点, 耐久力 4 点, 日常生活動作群 8.5 点, 可動域 26.3 点, X 線所見評価 5 点, 関節安定性 15 点であった.

調査時の肩関節平均可動域を表 1 に示す。健側と比 ベて屈曲, 外転, 外旋の各々で軽度の可動域制限を認 めた。

術後の合併症は 1 例に肩峰下インピンジメントを発

表 1 調查時肩関節可動域

\begin{tabular}{c|c|c}
\hline \hline $\mathrm{n}=7$ & 患側 (範囲) & 健側との差 (筂囲) \\
\hline 外転 & $130^{\circ}(120 \sim 150)$ & $20^{\circ} \quad(10 \sim 45)$ \\
屈曲 & $131^{\circ}(110 \sim 160)$ & $22.5^{\circ}(0 \sim 40)$ \\
外旋 & $55^{\circ}(40 \sim 70)$ & $7.5^{\circ}(0 \sim 20)$ \\
内旋 & $\mathrm{Th} 9(\mathrm{Th} 8 \sim \mathrm{Th} 10)$ & 2.8 棘突起間 $(2 \sim 5)$ \\
\hline
\end{tabular}

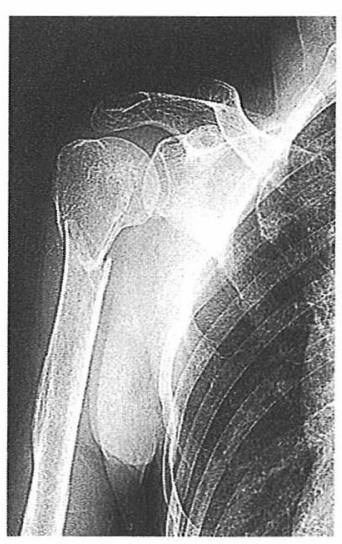

前後

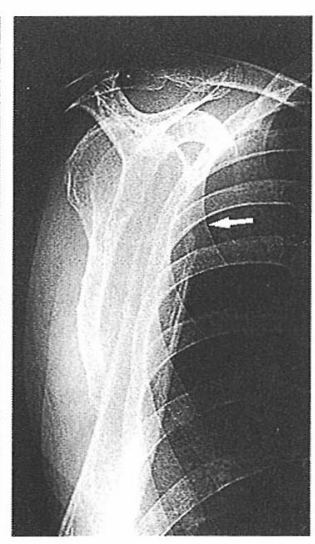

側面 : 遠位骨方の前方への 転位を認める。

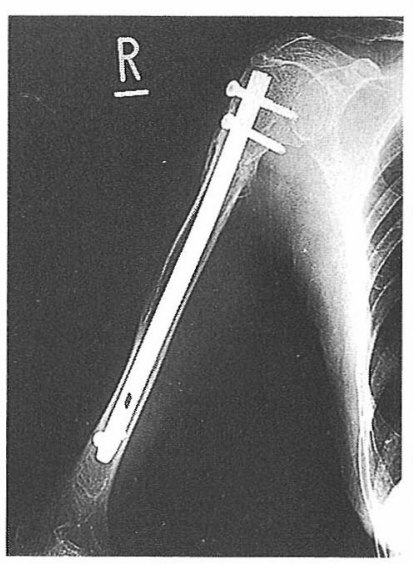

前後

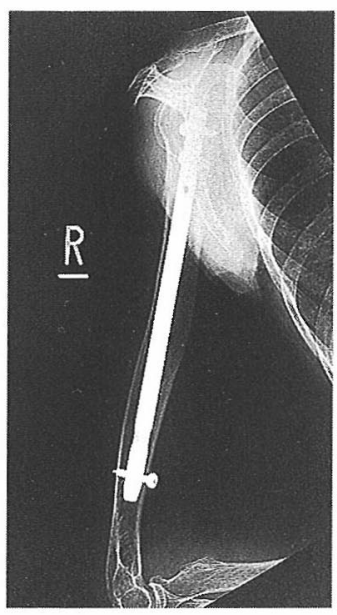

側面

a. 術前

b. 術後 5 力月

図 1 症例 172 才 


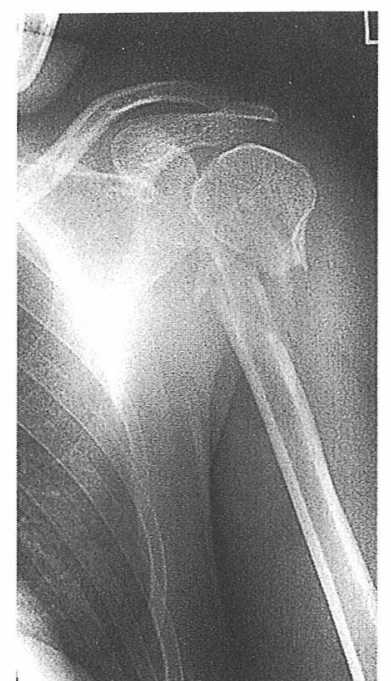

a. 術前

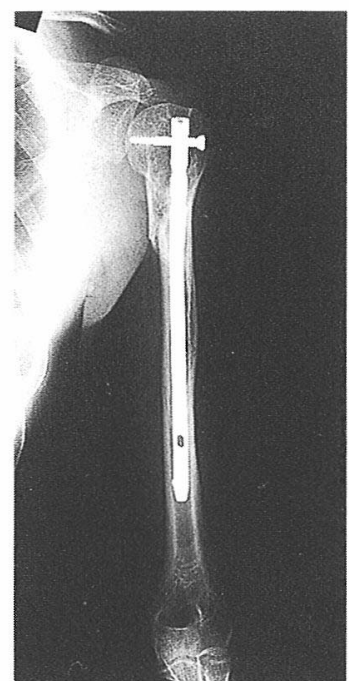

b. 術後 8 力月

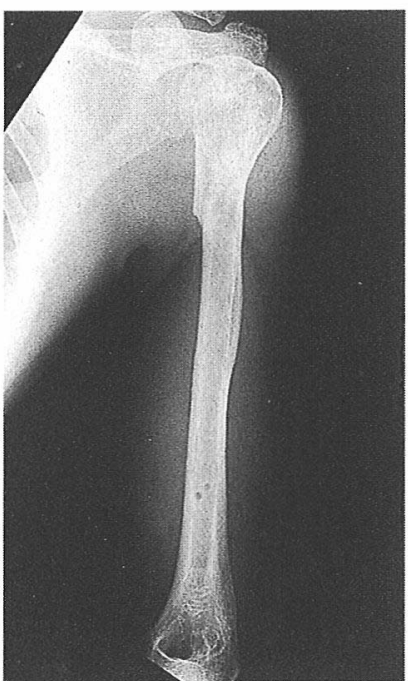

c. 抜釗後

図 2 症例 243 才男

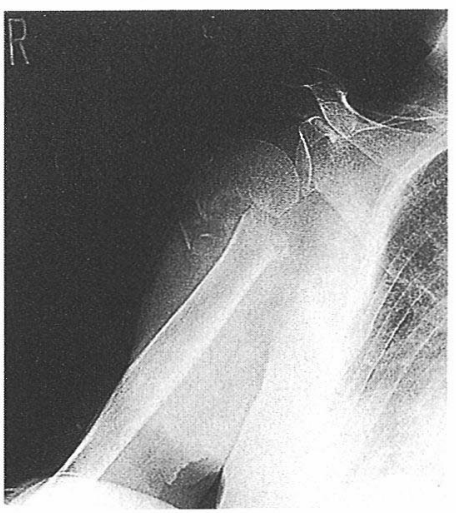

a. 術前

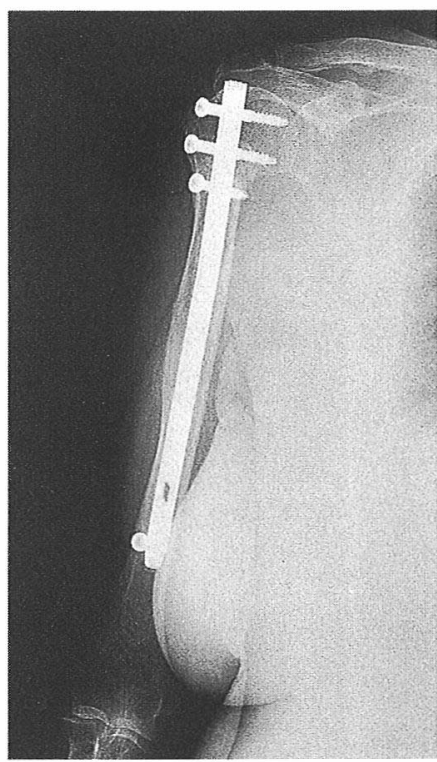

b. 術後 1 年 3 力月

髄内釷近位端の突出を認める。

図3 症例 377 才 


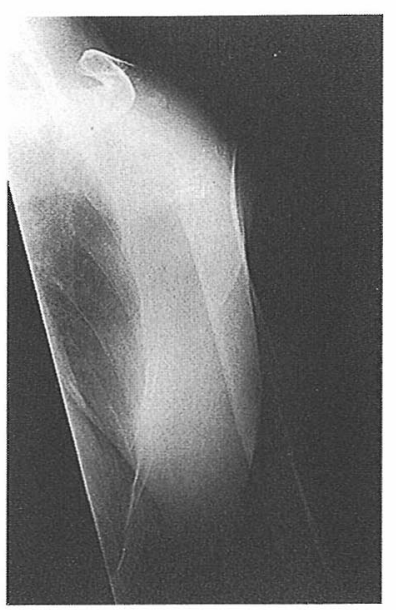

a. 術前

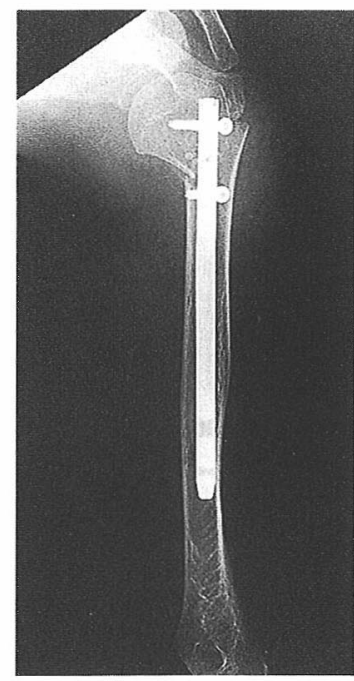

b. 術直後 骨折部での内反転位を認好る。

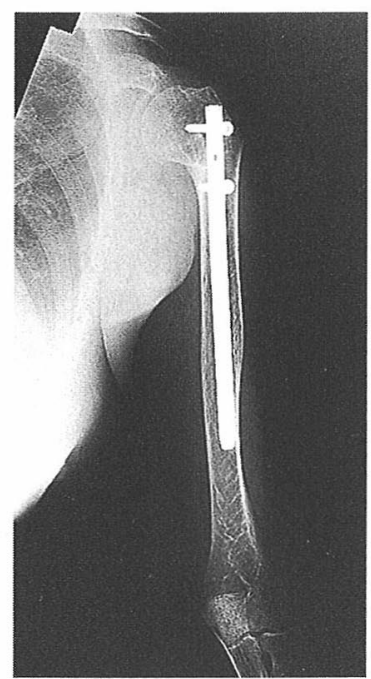

c. 術後 7 力月

図4 症例 458 才 女

生し，また他の 1 例で骨折部での著明な内反変形を生 じた。神経損傷, 感染, 肘関節の可動域制限を生じた 例はなかった。

症例を提示する。

症例 172 才女. 術前の X 線側面像で遠位骨片の 前方への転位を認めた。術後 5 カ月の時点で骨折部の 整復位および骨癒合は良好である。患側肩関節の可動 域は外転 $135^{\circ}$, 外旋 $65^{\circ}$, 内旋 Th9 と軽度の可動域 制限を認めるが肩の疼痛はなくJOA スコア 91 点で ある(図 1)。

症例 243 才男. 術前 X 線で骨折部の粉硚を認め た。術後 8 カ月の X線で骨折部の整復位および骨癒 合は良好である，患側肩関節の可動域制限を認めない が, 重労働時の軽度の肩関節痛を認め JOA スコアは 95 点. 術後 9 カ月で抜釷を行った（図 2).

症例 377 才女. 術前 X 線で骨折部の粉確を認め た。術後 1 年 3 力月の X 線で骨折部の整復位抢よび 骨癒合は良好であるが釘の近位端先端が骨頭表面より わずかに突出している。外転 $120^{\circ}$, 外旋 $55^{\circ}$, 内旋 Th9 と肩可動域制限を認める。また突出した釷の近 位端に起因する肩峰下インピンジメントによる挙上時 の肩関節痛を認めJOA スコア77.5 点である（図 3). 症例 458 才女. 術前 X 線で骨折部での内反転位
を認めた，術中の骨折部の整復が不十分であったため 術直後の X 線で骨折部の $50^{\circ}$ の内反転位を残した。 術後 7 カ月の時点で骨癒合は良好であるが肩外転 $120^{\circ}$ の可動域制限と疼痛を認め, JOA スコア 78.5 点 である(図 4).

考察

上腕骨近位端骨折に対する手術法としてはプレート 固定や Ender 釘を上腕骨頭あるいは上腕骨遠位側か ら刺入する方法, Kirschner 鋼線を上腕骨頭あるい は三角筋粗面から刺入する方法など種々の手技が行わ れてきた。しかし，いずれの方法でも高齢者の骨粗晹 症例においては骨折部の充分な固定性を得るのは困難 である ${ }^{1 / 316)}$.さらにプレート固定法や上腕骨頭側から 内固定材を刺入する方法では内固定材料の突出による 肩峰下インピンジメントを発生する可能性がある ${ }^{3)}$. また上腕骨遠位側からの刺入法では内固定材の脱落に よる固定性の喪失が報告されている ${ }^{6)}$.

これまで上腕骨近位端骨折に対する横止め髄内釘法 の報告は比較的少ない( ${ }^{5 / 778)}$. 今回我々はAce 䯣内釘を 用いた横止め髄内釘固定法を報告した。この方法では 横止め髄内釷に加えて髄内釷近位端にエンドキャップ を刺入し最近位の横止め螺子ロックするため, 術中の 
所見では骨粗琹症例に於ても骨折部の固定性は良好な 印象をもった。また骨折部を開かないため骨折部の血 行も温存されると思われる，以上より本術式は従来の 術式と比べて確実な骨癒合を得るという点で優れてい ると思われた。

一方, 本術式の問題点としては釷の刺入に際して腱 板を切開するため術後腱板障害が発生する可能性があ ることや，症例 3 で示した如く釷の近位端が関節面か ら突出した場合には肩峰下インピンジメントが発生す ることなどが挙げられる。このため手術施行時には釘 刺入後に切開した腱板の縫合をしっかり行うことや， 釘の設置に際して釘の近位端が関節面から突出しない ことなどに充分な注意を払う必要があると思われた。 また若年者で抜釷術を行う際にはもう一度腱板を切開 する必要があることも問題点と思われる．3part 骨折 は，釘の刺入部や横止め螺子の刺入部に骨折が及んで いることが多いため，Ace 髄内釷では充分な固定性 が得がたいと思われ本術式の適応外と考える ${ }^{8}$.

\section{結語}

(1) Ace 上腕骨髄内釷を用いて横止め髄内釷固定法 を行った 2 part 上腕骨外科澒骨折 7 例の術後成績を 検討した。

(2)骨癒合は全例で得られ，遷延癒合例はなかった。
(3)調査時 JOA スコアは平均 85.5 点であり, 肩関 節の軽度の可動域制限を残した。

(4) 1 例で骨折部での著明な内反変形を生じ，他の 1 例では釘を近位端の突出による肩峰下インピンジメン 卜を合併した。

\section{参 考 文 献}

1）青木光広ほか：高齢者の上腕骨外科頻骨折に対する Ender 釷の術後成績. 別冊整形外科, $21: 35-39,1992$.

2) Jaberg, H., Warner, J. J., Jakob, R. P.: Percutaneous stabilization of unstable fractures of the humerus. J Bone Joint Surg, 74A : 508-515, 1992.

3) Kristiannsen, B., Christensen, S. W.: Plate fixation of proximal humeral fractures. Acta Orthop Scand, $57: 320-323,1986$.

4) Neer, C.S.: Displaced proximal humeral fractures: Part I. Classification and evaluation. J Bone Joint Surg, 52A : 1077-1103, 1970.

5）野々宮廣章：上腕骨骨折に対する䯣内釷固定。最小信 襲ジャーナル, 4:21-30, 1997.

6）小川清久：上腕骨近位端骨折に対する Kirschner 鋼線 䯣内固定法. 別冊整形外科, $21: 22-26,1992$.

7）高橋信男ほか：上腕骨近位端骨折に対する humeral nail の経験。中部整災誌，40：1501-1502，1997,

8）山根慎太郎，末永直樹，三浪明男：上:腕骨近位端骨折 に対する横止め䯣内釗固定法. 別冊整形外科， $36 ： 217$ $220,1999$. 